Side-effects on indomethacin capsules, at an average maintenance dose of $75 \mathrm{mg}$. daily, occurred in $36.6 \%$ of patients in the mixed group. The common side-effects were headache, giddiness, muzziness, nausea, and vomiting. Dyspepsia was not a major problem, occurring in $7.92 \%$ of patients; it was only rarely dose-dependent and occurred at any time during long-term administration in contrast to the other side-effects, which were dependent on dose and developed almost always within the first 14 days of treatment.

\section{Addendum}

Since the completion of this study, one patient on indomethacin, $200 \mathrm{mg}$. daily, and prednisolone, $8 \mathrm{mg}$. daily, with a history of duodenal ulceration, present 20 years earlier, developed dyspepsia after six months on indomethacin. This was followed by a haematemesis which required blood transfusion. In many of the cases of haematemesis reported this combination of drugs was used.

We would like to thank Dr. R. Hodgkinson, of Merck, Sharp, and Dohme Ltd., for generous supplies of indomethacin.
American Rheumatism Association Committee (1959). Ann. rheum. Dis., $18,49$.

Ballabio, C. B., Cirla, E., Girardi, G., Caruso, I., and Colombo, B. (1963). Rheumatismo, 15, 487.

Bilka, P. J., Wollheim, F., and Williams, R. C., jun. (1964). Minn. Med., $47,777$.

Boardman, P. L., and Hart, F. Dudley (1965). Practitioner, 194, 560. atoggio, P. M., Centurion, A., Alberti, H., Roldan, H., and Canepa, L. Clark, G. Arthr. and Rheum., 7, 300.

Clark, G. M. (1964). Ibid., 7, 300 .

ixon, A. St. J., Jones, L., Wanka, J., and Wood, P. (1963). Abstracts of Communications, Fifth European Congress on Rheumatic Hart, F. Dudley, and

Lör (1964). Practitioner, 192, 828.

Paul, W. ., and Allander, E. (1964). Brit. med. F., 1, 118.

, W. D., and Strottman, M. P. (1963). Arthritis and Rheumatism Foundation (Iowa) Medical Information Bulletin, 4 (3), 1.

(1963). Abstracts of Communications, Fifth European Congress on Rheumatic Diseases, p. 176.

Rheum., 6, 299.

Stein Amoroso, C., and Valayos, E. (1964). Ibid., 7, 345.

Steinbrocker, O., Traeger, C. H., and Batterman, R. 345. med. Ass., 140, 659 .

\title{
Heroin Addiction in the United Kingdom (1954-1964)
}

\author{
THOMAS BEWLEY,* M.D., F.R.C.P.I., D.P.M.
}

Brit. med. F., 1965, 2, 1284-1286

The pattern of narcotic addiction in the United Kingdom has changed in the past 10 years. Most addicts recorded before 1954 had become addicted accidentally in the course of therapy or belonged to professions with easy access to drugs-for example, doctors, nurses, and pharmacists. Since then the number of younger addicts has grown, mostly from contact with other addicts. The slow fall in the number of known addicts on the Home Office index has changed to a rising number, suggesting that two separate processes were at work, the increase being due to an increasing number of "nontherapeutic" addicts (Lancet, 1964). This paper reports a fresh survey of all the heroin addicts known to the Home Office between 1954 and 1964 inclusive. Heroin addicts were chosen for this survey because most of the newly recorded addicts took this drug. Their number has increased strikingly compared with those addicted to other narcotics (Official Reports).

\section{Home Office Figures}

The index or register kept by the Home Office is commonly misunderstood. It is compiled from information reaching the Home Office from various sources. The most important are the routine inspections of retail pharmacists' records. These inspections are carried out by the police, and when they show regular or unusual supplies of drugs to particular individuals this is reported to the Home Office. Further inquiry is made, usually by a regional medical officer of the Ministry of Health, or Scottish Home and Health Department, to discover whether the case is one of addiction or of genuine medical necessity. The police also report cases of addiction encountered in the course of other inquiries. Further cases may be reported to the Home Office by doctors, hospitals, social workers, or similar sources. Addiction is not at present notifiable, and doctors have no statutory duty to report such cases. However, if a doctor prescribes narcotic drugs for an addict, the addict's name will eventually reach the index after inspection of the records of the pharmacist dispensing the drugs.

The annual statistics published by the Home Office show only

* Consultant Psychiatrist, Tooting Bec Hospital, London S.W.17. those addicts known to have been taking drugs during the previous year. They exclude those who are not known to be currently taking drugs-for example, addicts in prison, abroad, those obtaining all their drugs from illicit sources, as well as those permanently or temporarily cured. These figures do not give an accurate estimate of the total number of addicts, for three groups will not be noted:

(1) Those in the early stages who obtain all their drugs from addict friends or other black-market source.

(2) Those who do this permanently, who will never be known to the Home Office unless notified by the police.

(3) Those who have temporarily had their names removed from the register for one of the reasons already given.

Most of the addicts on the index have usually been addicted for a year when first noted, so that the numbers recorded will always be a year behind the true figure.

\section{Results of Survey}

This survey reviews every person known to be addicted to heroin in 1954 and all further cases of this addiction notified from then until the end of 1964 . Fifty-seven heroin addicts were known in 1954 and 450 new cases were added in the following 10 years. A separate form was prepared giving date of birth, sex, nationality, source of addiction, and the state of addiction in each of the succeeding years to 1964. All deaths were recorded, with the cause where known. The present figures differ slightly from those previously published as further information has become available. For example, some people in earlier reports had been using assumed names ; others believed to have disappeared had died; and some believed off drugs in a particular year are now known to have been addicted then.

Most new cases since 1955 have been British. The number has increased and the rate is accelerating (Table I). If this continues, between 200 and 300 new British heroin addicts will be recorded in 1965 and a further increase later. Most had become addicted from some non-therapeutic source (Table II). They fell into three age groups (Table III). Those who became addicted in the course of treatment were aged over 60 . British 
addicts addicted from a non-therapeutic source had a mean age of 24 years. Those of other nationalities had a mean age of 32 years. Most of the members of this last group had been addicted for many years before coming to this country. The decrease in the mean age of addicts each year has been due to an increasing number of younger addicts addicted from a nontherapeutic source. It has not been due to a progressive decrease in the age at which they have become addicted (Table IV). The outcome for each individual has been recorded yearly (Tables V and VI). All those known to be taking heroin are correctly recorded, but those not known to be taking drugs probably include some who are still addicted. The number of those off drugs is overstated. Of the 507 known addicts, 325 have been continuously taking heroin and 84 are not known to be taking heroin (Table VII). Forty-two of the addicts had died before 1964 and a further 13 subsequently. Twenty-one of those who died had become addicted in the course of treatment, 34 from some non-therapeutic source. The mean age at the time of death of the addicts who had acquired their addiction from other than medical sources was 34 years (Table VIII).

\section{Discussion}

The number of recorded heroin addicts in the United Kingdom has increased yearly. The rate of appearance of new cases is also increasing. New cases reported double every 18 months. These figures do not accurately estimate the total number of heroin addicts. They are a year behind the true figure and some other addicts are not recorded. Those off drugs are overestimated-for example, some recorded as not taking drugs may be obtaining drugs illicitly; others may be taking

\begin{tabular}{|c|c|c|c|c|c|c|}
\hline & \multicolumn{3}{|c|}{ British } & \multirow{2}{*}{ Canadian } & \multirow{2}{*}{$\begin{array}{l}\text { Other } \\
\text { Nation- } \\
\text { ality* }\end{array}$} & \multirow{2}{*}{ Total } \\
\hline & Men & Women & Total & & & \\
\hline $\begin{array}{l}1955 \\
1956 \\
1957 \\
1958 \\
1959 \\
1960 \\
1961 \\
1962 \\
1963 \\
1964\end{array}$ & $\begin{array}{r}4 \\
5 \\
5 \\
3 \\
4 \\
11 \\
18 \\
39 \\
54 \\
98\end{array}$ & $\begin{array}{r}5 \\
5 \\
2 \\
8 \\
6 \\
4 \\
9 \\
10 \\
23 \\
35 \\
\end{array}$ & $\begin{array}{r}99 \\
10 \\
7 \\
11 \\
10 \\
15 \\
27 \\
49 \\
77 \\
133 \\
\end{array}$ & $\begin{array}{r}0 \\
0 \\
0 \\
0 \\
1 \\
4 \\
24 \\
16 \\
10 \\
15\end{array}$ & $\begin{array}{r}1 \\
0 \\
0 \\
0 \\
0 \\
4 \\
5 \\
5 \\
3 \\
14\end{array}$ & $\begin{array}{c}10 \\
10 \\
7 \\
11 \\
11 \\
23 \\
56 \\
70 \\
90 \\
162\end{array}$ \\
\hline $\begin{array}{r}\text { Total for } \\
\text { decade }\end{array}$ & 241 & 107 & 348 & 70 & & 450 \\
\hline \multicolumn{7}{|c|}{$\begin{array}{l}\text { *Includes: United States, 13; Jamaica, 8; India, 3; Australia, 3; New Zealand, } \\
\text { 2; Other, 3. } \\
\text { TABLE II.-Source of Addiction of All Recorded Heroin Addicts in the } \\
\text { United Kingdom Since 1954 }\end{array}$} \\
\hline & & \multicolumn{2}{|c|}{$\begin{array}{l}\text { Addiction Acquired in } \\
\text { Course of Treatment }\end{array}$} & \multicolumn{2}{|c|}{$\begin{array}{l}\text { Addiction Acquired } \\
\text { from Some Other Source }\end{array}$} & Total \\
\hline \multicolumn{2}{|c|}{$\begin{array}{l}\text { Known to be } \\
\text { addicted in } 1954 \\
\end{array}$} & \multicolumn{2}{|c|}{$\left.\begin{array}{lr}\text { Men } & 6 \\
\text { Women } & 14\end{array}\right\} 20$} & \multicolumn{2}{|c|}{$\left.\begin{array}{ll}\text { Men } & 23 \\
\text { Women } & 14\end{array}\right\} 37$} & 57 \\
\hline \multicolumn{2}{|c|}{$\begin{array}{l}\text { New cases since } \\
1954\end{array}$} & \multicolumn{2}{|c|}{$\left.\begin{array}{ll}\text { Men } & 7 \\
\text { Women } & 7\end{array}\right\} 14$} & \multicolumn{2}{|c|}{$\left.\begin{array}{l}\text { Men } 321 \\
\text { Women } 115\end{array}\right\} 436$} & 450 \\
\hline
\end{tabular}

TABLE III.-Mean Age of All Heroin Addicts When First Known to be

\begin{tabular}{|c|c|c|c|}
\hline Nationality & Source of Addiction & No. of Cases & Mean Age \\
\hline British $\ldots$ & Medical treatment & $\left.\begin{array}{ll}\text { Men } & 7 \\
\text { Women } & 7\end{array}\right\} 14$ & \begin{tabular}{ll|}
\multicolumn{2}{c|}{$60 \cdot 7$ years } \\
Men & 69.0 \\
Women & $53 \cdot 4$ \\
\end{tabular} \\
\hline British .. & Non-therapeutic & $\left.\begin{array}{ll}\text { Men } & 224 \\
\text { Women } & 100\end{array}\right\} 334$ & \begin{tabular}{ll}
\multicolumn{2}{c}{$23 \cdot 6$ years } \\
Men & $24 \cdot 6$ \\
Women & $21 \cdot 8$ \\
\end{tabular} \\
\hline Canadian & All non-therapeutic & $\begin{array}{lr}\text { Men } & 61 \\
\text { Women } & 9\end{array} 70$ & $\begin{array}{ll} & 31.7 \text { years } \\
\text { Men } & 31.9 \\
\text { Women } & 30 \cdot 6\end{array}$ \\
\hline Other nationality & All non-therapeutic & $\left.\begin{array}{lr}\text { Men } & 26 \\
\text { Women } & 6\end{array}\right\} 32$ & $\begin{array}{lr}30 \cdot 0 \text { years } \\
\text { Men yen } 30.2 \\
\text { Women } & 29 \cdot 6 \\
\end{array}$ \\
\hline$\overline{\text { All heroin addicts }}$ & All sources & $\left.\begin{array}{ll}\text { Men } & 328 \\
\text { Women } & 122\end{array}\right\} 450$ & $\begin{array}{ll} & 26 \cdot 7 \text { years } \\
\text { Men } & 26 \cdot 9 \\
\text { Women } & 26 \cdot 2\end{array}$ \\
\hline
\end{tabular}

barbiturates (Isbell, 1950); and some names recorded as taking heroin for a time and then ceasing may be assumed names later recorded correctly. Despite this only a very small proportion of all addicts may be off drugs. Over $82 \%$ continuously take drugs or have died.

There are three groups of heroin addicts in the United Kingdom at present:

(1) A small number of addicts who have become addicted in the course of treatment.

Table IV.-Mean Age of Heroin Addicts When First Known to be Addicted, 1960-1965

\begin{tabular}{|c|c|c|c|c|c|}
\hline & 1960 & 1961 & 1962 & 1963 & 1964 \\
\hline \multicolumn{6}{|l|}{ tish } \\
\hline $\begin{array}{l}\text { Men } \\
\begin{array}{l}\text { Women } \\
\text { Canadian (non-thera- }\end{array}\end{array}$ & $\begin{array}{l}28 \cdot 7(9) \\
24 \cdot 2(4)\end{array}$ & $\begin{array}{l}23.6(16) \\
27.4(9)\end{array}$ & $\begin{array}{l}22.9(39) \\
22 \cdot 0(10)\end{array}$ & $\begin{array}{l}23.6(54) \\
21.8(23)\end{array}$ & $\begin{array}{l}23.5(98) \\
21.9(34)\end{array}$ \\
\hline $\begin{array}{l}\text { peutic) } \\
\text { Other (non-thera- }\end{array}$ & $37 \cdot 5(4)$ & $29 \cdot 2(24)$ & $31 \cdot 1(16)$ & $33.8(10)$ & $32.9(15)$ \\
\hline $\begin{array}{cc}\text { peutic) } \\
\text { All addicts }\end{array}$ & $31 \cdot 2(4)$ & $31.6(5)$ & $27 \cdot 8(5)$ & $32 \cdot 6(3)$ & $29.4(14)$ \\
\hline " (non-therapeutic) & $30 \cdot 4(21)$ & $28.6(54)$ & $25.0(70)$ & $24 \cdot 7(90)$ & $24 \cdot 4(161)$ \\
\hline addicts & $-(2)$ & $-(2)$ & $-(0)$ & $-(0)$ & $-(1)$ \\
\hline
\end{tabular}

Figures in brackets give the number of addicts in each group.

TABLE V.-Follow-up of All Heroin Addicts First Recorded, 1955-1964

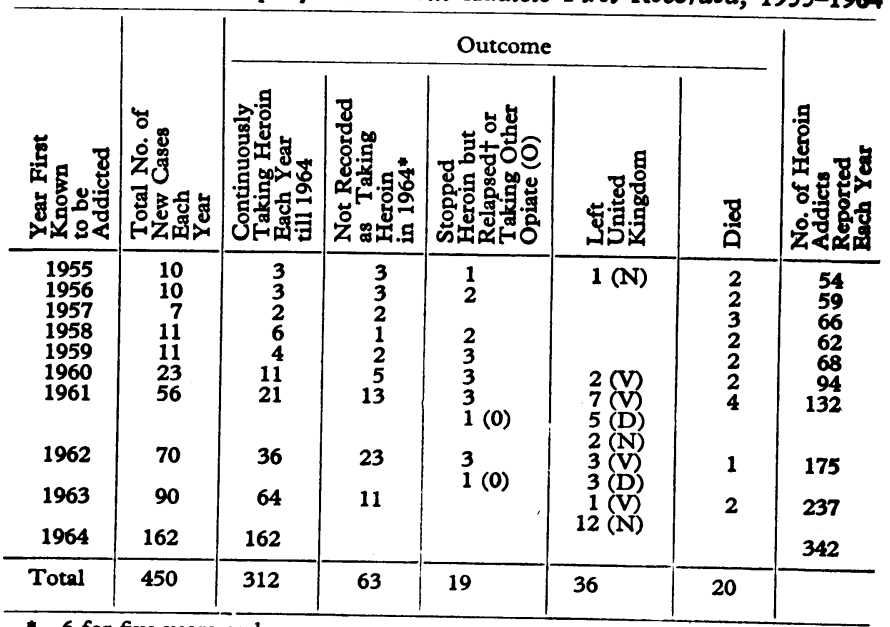

$*=6$ for five years or longer.

$t=4$ are again not recorded to be taking drugs.

TABLB VI.-Follow-up of All Heroin Addicts Recorded in 1954 (16 New

\begin{tabular}{|c|c|c|c|c|c|}
\hline \multirow{2}{*}{$\begin{array}{c}\text { Year } \\
\text { Addiction } \\
\text { First } \\
\text { Noted }\end{array}$} & \multirow{2}{*}{$\begin{array}{l}\text { No. of } \\
\text { Cases }\end{array}$} & \multirow{2}{*}{$\begin{array}{c}\text { Taking } \\
\text { Heroin } \\
\text { Each Year } \\
\text { till } 1964 \\
\end{array}$} & \multirow{2}{*}{$\begin{array}{c}\text { Other. Not } \\
\text { Recorded } \\
\text { Taking } \\
\text { Drugs 1964* }\end{array}$} & \multicolumn{2}{|c|}{ Died } \\
\hline & & & & $\begin{array}{l}\text { "Thera- } \\
\text { peutic" }\end{array}$ & $\begin{array}{c}\text { "Non- "Noperic " } \\
\text { therape }\end{array}$ \\
\hline $\begin{array}{c}\text { Not known } \\
1932-4 \\
1935-7 \\
1938-40 \\
1941-3\end{array}$ & $\begin{array}{l}3 \\
3 \\
4 \\
6 \\
4\end{array}$ & $\begin{array}{l}1 \\
1 \\
1 \\
2\end{array}$ & $\begin{array}{l}1 \\
3 \\
1(R) \\
1(O)\end{array}$ & $\begin{array}{l}3 \\
1 \\
1 \\
2\end{array}$ & $\begin{array}{l}1 \\
1\end{array}$ \\
\hline $\begin{array}{l}1944-6 \\
1947-9 \\
1950-1 \\
1952-3\end{array}$ & $\begin{array}{r}4 \\
2 \\
3 \\
12\end{array}$ & $\begin{array}{l}1 \\
1 \\
2 \\
2\end{array}$ & $\begin{array}{l}1 \\
1 \\
3 \\
2(R)\end{array}$ & 2 & 1 \\
\hline 1954 & 16 & 2 & $\begin{array}{l}7(\mathrm{~K}) \\
1(\mathrm{R}) \\
1(\mathrm{~N})\end{array}$ & 2 & 3 \\
\hline Total & 57 & 13 & 22 & 13 & 9 \\
\hline
\end{tabular}

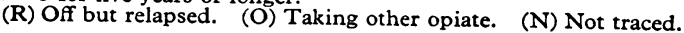

TABLE VII.-Present Addiction Status of All Heroin Addicts

\begin{tabular}{c|c|c|c|c|c|c|c|c|c}
\hline No. of Years: & 1 & 2 & 3 & 4 & 5 & 6 & 7 & Over & Total \\
\hline $\begin{array}{c}\text { Continuously } \\
\text { taking heroin } \\
\begin{array}{c}\text { Not known to } \\
\text { be taking } \\
\text { heroin or } \\
\text { other opiate }\end{array}\end{array}$ & 33 & 64 & 36 & 21 & 11 & 4 & 6 & 21 & 325 \\
\hline
\end{tabular}

Other outcome: Died, 42; readdicted to heroin or other opiate, 19; left United
ingdom, 21; disappeared, 16 . 
TABLE VIII.-Causes of Deaths*

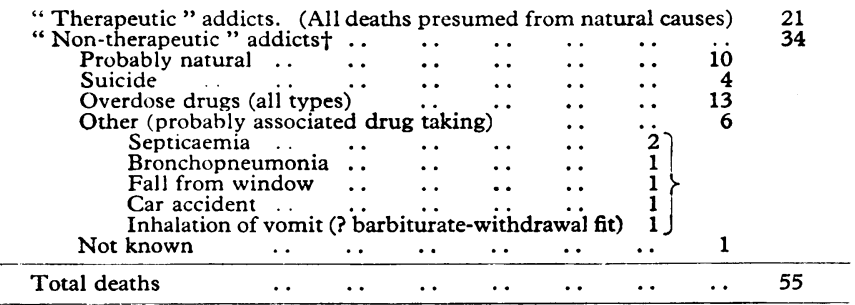

* Includes 13 subsequent deaths.

+ Mean age of "non-therapeutic" addicts at death 34 years.

(2) A large group of young British addicts, rapidly increasing, whose members have acquired their addiction from some non-therapeutic source.

(3) A group of older addicts who came to this country after the rise in numbers was first noted. The mean age of this group is 10 years higher than that of the British addicts. Most have been addicted for many years, having become addicted from a non-therapeutic source.

Addicts who have become addicted from a non-therapeutic source act as a further source of spread of addiction (Bewley, 1965). Those addicted in the course of treatment do not do this. The probable reason is that the former group contain a greater number of addicts with deviant personalities and with less satisfactory backgrounds (Chien, 1964).

\section{Conclusions}

The results of treatment of this type of addiction are very poor. Retterstol and Sund (1964) showed that despite careful treatment of drug abusers with a better prognosis, $60 \%$ continued to misuse drugs. Where poorly motivated addicts have been treated, only $10 \%$ to $30 \%$ may give up drugs (Hunt and Odoroff, 1962 ; Duvall et al., 1963). In view of this very poor response to treatment prevention is important. The practice of prescribing drugs for maintenance of addicts worked successfully only when the majority of addicts become addicted from treatment. Treating other addicts this way makes it easier for new individuals to become addicted to these drugs. Liberal prescribing has no beneficial effect on the addict (Glatt, 1965).
The chief source of illicit heroin and cocaine in this country is the sale of these drugs by addicts who have more than they' need prescribed for them (Howard, 1965 ; James, 1965). It is essential to limit the prescribing of heroin for addicts. The argument that this might lead to the creation of a black market is irrelevant, as the present practice supplies drugs free for illicit sale and encourages spread of further addiction. Addiction of this type with epidemic case-to-case spread is a Public Health problem and should be recognized as such. Statutory notification of addiction and case finding among contacts are necessary. More up-to-date information should be available. As previously suggested, a special treatment unit or treatment units and continuous review of the problem would also be desirable (Lancet, 1965).

\section{Summary}

A survey and follow-up is presented of the 507 recorded heroin addicts in the United Kingdom between 1954 and 1964. The rate of appearance of new cases has steadily increased. Over $80 \%$ of all addicts remained addicted or died. Present methods of dealing with this addiction are ineffectual. Preventive measures are recommended, including limitations on prescribing heroin for addicts.

I would like to thank the Home Office for giving me every facility to carry out this survey and particularly Mr. H. B. Spear, whose invaluable help has made it possible.

\section{REFERENCES}

Bewley, T. (1965). Lancet, 1, 808.

Chein, I., Gerard, D. L., Lee, R. S., and Rosenfeld, E. (1964). Narcotics Delinquency and Social Policy. Basic Books, New York, U.S.A.

Duvall, H. J., Locke, B. Z., and Brill, L. (1963). Publ. Hith Rep. (W ash.), 78, 185.

Glatt, M. M. (1965). Lancet, 2, 171.

Howard, A. (1965). Med.-leg. f. (Camb.), 33(2), 56.

Hunt, G. H., and Odoroff, M. E. (1962). Publ. Hith Rep. (Wash.), 77,

Isbell, H., Altschul, S., Kornetsky, C. H., Eisenman, A. J., Flanavy, H. G., and Fraser, H. F. (1950). Arch. Neurol. Psychiat. (Chic.), 64, 1 .

James, I. P. (1965). Lancet, 2, 288.

Lancet, 1964, 1, 649.

Lancet 1965, 2, 169.

Reports to the United Nations on the Working of the International Treaties on Narcotic Drugs. Home Office, London (1954-1964). Retterstol, N., and Sund, H. (1964). Acta psychiat. scand., 40, Suppl.
No. 179.

\title{
Laboratory Diagnosis of Infections of the Urinary Tract in General Practice by Means of a Dip-inoculum Transport Medium
}

\author{
J. P. MACKEY,* M.B., F.C.PATH., D.P.H., D.T.M.\&H., DIP.BACT. ; G. H. SANDYS,* F.I.M.L.T.
}

Brit. med. F., 1965, 2, 1286-1288

The frequency and importance of infections of the urinary tract are now generally recognized, especially in females and particularly in pregnancy, and the possible association with the later development of chronic pyelonephritis (Kass, 1960 ; Brumfitt and Percival, 1964).

Most of these infections may be diagnosed and treated in the patients' homes by the general practitioner (Mond, Percival, Williams, and Brumfitt, 1965 ; Gallagher, Montgomerie, and North, 1965) if bacteriological facilities are available.

The laboratory diagnosis requires an assessment of the bacterial concentration in the freshly passed "clean" midstream specimen of urine in order that one can distinguish the

* Public Health Laboratory, Bath. "significant" bacteriuria of infection (usually greater than 100,000 bacteria per $\mathrm{ml}$. of urine) from the relatively low bacterial concentration (under $10,000 / \mathrm{ml}$.) associated with the presence of contaminant bacteria only (Kass, 1956).

The most satisfactory way of assessing the bacterial concentration in a sample of urine is by a viable count, for which a number of techniques are available. All of them, however, depend on the rapid transmission of the specimen to the laboratory, and refrigerator storage if there is a delay before dispatch. In our experience the average general practitioner is seldom able to deliver the sample of urine to the laboratory quickly enough. Even if this could be done he must often want to take the specimen before prescribing treatment, at times when the laboratory is closed except for emergency work. For these and other reasons the practice of submitting samples of urine 